\title{
Influence of site, storage and steaming on Eucalyptus nitens log-end splitting
}

\author{
Mario Vega ${ }^{1,2}$ - Matthew G. Hamilton ${ }^{3}$ • David P. Blackburn ${ }^{4}$. \\ Robert L. McGavin ${ }^{2,5,6}$ • Henri Baillères ${ }^{2,6}$ - Brad M. Potts ${ }^{1,2}$
}

Received: 19 March 2015 / Accepted: 5 June 2015 /Published online: 2 July 2015

(C) INRA and Springer-Verlag France 2015

\begin{abstract}
- Key message Log-end splitting is one of the single most important defects in veneer logs. We show that log-end splitting in the temperate plantation species Eucalyptus nitens varies across sites and within-tree log position and increases with time in storage.

- Context Log-end splitting is one of the single most important defects in veneer logs because it can substantially reduce the recovery of veneer sheets. Eucalyptus nitens can develop log-end splits, but factors affecting log-end splitting in this species are not well understood.
\end{abstract}

Handling Editor: Jean-Michel Leban

Contribution of the co-authors All authors undertook writing/editing of the manuscript, and all, except Brad Potts (BMP), were involved in data collection. David Blackburn and Matthew Hamilton (MGH) were responsible for log selection and supply logistics. Mario Vega, MGH and BMP undertook statistical analyses. Mario Vega wrote the first draft of the manuscript, assisted by MGH and BMP. Robert McGavin and Henri Bailleres were actively involved in the design of the experiment and oversaw the processing of logs.

Mario Vega

mhvega@utas.edu.au

Matthew G. Hamilton

matthew.hamilton@csiro.au

David P. Blackburn

david.blackburn@utas.edu.au

Robert L. McGavin

robbie.mcgavin@daff.qld.gov.au

Henri Baillères

henri.bailleres@daff.qld.gov.au

Brad M. Potts

b.m.potts@utas.edu.au

1 School of Biological Sciences, University of Tasmania (UTAS), Private Bag 55, Hobart, Tasmania 7001, Australia
- Aims The present study aims to describe the effect of $\log$ storage and steaming on the development of log-end splitting in logs from different plantations and log positions within the tree.

- Methods The study was conducted on upper and lower logs from each of 41 trees from three 20-22-year-old Tasmanian $E$. nitens plantations. Log-end splitting was assessed immediately after felling, after transport and storage in a log-yard, and just before peeling. A pre-peeling steam treatment was applied to half the logs.

- Results Site had a significant effect on splitting, and upper logs split more than lower logs with storage. Splitting increased with tree diameter breast height $(\mathrm{DBH})$, but this relationship varied with site. The most rapidly growing site had more splitting even after accounting for DBH. No significant effect of steaming was detected.

- Conclusion Log-end splitting varied across sites and withintree $\log$ position and increased with time in storage.

2 National Centre for Future Forest Industries, Private Bag 55, Hobart, Tasmania 7001, Australia

3 Integrated Sustainable Aquaculture Production, Agriculture Flagship, Commonwealth Scientific and Industrial Research Organisation (CSIRO), Castray Esplanade, Hobart, Tasmania 7000, Australia

4 Centre for Sustainable Architecture with Wood, School of Architecture and Design, University of Tasmania, Private Bag 65, Hobart, TAS 7001, Australia

5 Department of Forest Ecosystem Science, University of Melbourne, 500 Yarra Boulevard, Richmond, Victoria 3121, Australia

6 Queensland Department of Agriculture, Fisheries and Forestry, Horticulture and Forestry Science, Salisbury Research Facility, 50 Evans Road, Salisbury, Queensland 4107, Australia 
Keywords Growth stress · Splits · Veneer · Plantation · Log position

\section{Introduction}

There are over 20 million hectares of eucalypt plantations in the world (Iglesias-Trabado and Wilstermann 2009). While most eucalypt plantations are grown for pulpwood, 1.2 million hectares are managed for sawlog production (FAO 2005). Log-end splitting is one of the many factors affecting the recovery of timber and veneer from plantation-grown eucalypts (Priest et al. 1982; Bariska 1990; Yang et al. 2005; Chauhan et al. 2006). It manifests immediately after felling and tends to increase further with time in storage.

Log-end splitting occurs as a consequence of growth stress (Kubler 1987). Growth stress is generated during cell maturation in the cambium zone (Yang et al. 2005). These forces produce tension in the cells near the cambium, while the cells near the pith are in compression. This contrast generates a residual stress distribution (Kubler 1987; Okuyama 1997; Chauhan et al. 2006). When a tree is felled or a log is crosscut, the elastic energy of the residual stress is released through formation of end splits at the cross-cut surface (Okuyama 1997). In the absence of drying with shrinkage, cross-cutting creates a free surface in a pre-stressed volume (growth stress field) which leads to a redistribution of stresses. On a log end, this is equivalent to axially pulling its centre and applying a pressure on its periphery (Archer 1987). These forces induce heart splitting when the radial stress generated by the redistribution reaches the ultimate strength of green wood in the tangential direction. From a solid mechanics point of view, the initiation and progression of the cracks depend on the geometry of the log, the growth stresses, the elastic and non-elastic mechanical properties and the transverse strength or toughness of green wood (Jullien et al. 2003). The mechanical properties, tangentially to the $\log$ axis, can be significantly affected by grain angle and the end-split pattern

Growth stress and consequently log-end splitting varies within and among trees, as well as among sites, and are potentially influenced by genetic, environmental and silvicultural factors (Archer 1987; Kubler 1988). Genetic effects in Eucalyptus, for example, have been reported at the clonal (Malan and Verryn 1996), family (Barros et al. 2002), provenance and species levels (Nixon 1991). In addition, Nixon (1991) found that $E$. nitens showed the lowest level of splitting when it was compared among 13 different eucalypt species in South Africa. Environmental factors which can increase growth stress include those which cause stem re-orientation, such as slope, aspect and wind exposure (Archer 1987; Kubler 1987; Malan and Verryn 1996). These factors affect the manner in which the stem and crown are oriented, inducing a redistribution of internal growth stress in the stem (Kubler 1988; Mattheck and Kubler 1997). Wind pressure, for example, has been observed to promote splits at right angles to the main wind direction (Mattheck and Kubler 1997).

Silvicultural practices can also influence the magnitude of growth stress (Malan 1995). Thinning is the most important silvicultural intervention in terms of its effect on growth stress and log-end splitting because it affects competition among trees. Thinned stands, which experience lower competition, produce trees with high taper and large crown, which tend to exhibit low growth stress (Mattheck and Kubler 1997). In contrast, trees under strong competition have slender stems and narrow crowns and exhibit high levels of growth stress (Becker and Beimgraben 2002). However, the effect of competition on growth stresses may change with development stage of the stand (Biechele et al. 2009). When thinning is frequent and light, trees do not need to re-orientate their crowns to catch light, so growth stresses are likely to be lower. On the other hand, infrequent and heavy thinning results in drastic changes in the amount and direction of light, which may lead to high growth stress (Kubler 1988).

In addition to these genetic, environmental and silvicultural influences on growth stress, there are industrial factors that directly affect the magnitude of log-end splitting during processing. In veneer processing, the most relevant factors are storage time and log heating. Logs are commonly stockpiled to avoid production stoppages or to buffer the production system against market price fluctuations (Shmulsky 2002). In eucalypt logs, two phases of split development during storage have been described (Priest et al. 1982; Bariska 1990 ). The first phase starts immediately after felling, with splitting increasing rapidly until 6 to 20 days after felling. This is followed by a second phase when splitting is significantly slower. In terms of the wood supply chain, the first splitting phase usually occurs between felling and the log-yard, whereas the second phase is usually evident after storage in the log-yard prior to processing.

Heating hardwood logs using hot water or steam is common practice prior to peeling for veneer (Shmulsky 2002). This is done to improve veneer yield, smoothness and thickness uniformity and to reduce energy consumption (Becker and Beimgraben 2002 ; Dupleix et al. 2012). In species prone to developing high growth stresses, log heating has been reported to relieve growth stresses and improve timber quality (Severo et al. 2010). However, heating logs at high temperatures can also exacerbate logend splits (Marchal et al. 1993). This is believed to be due to the expansion and contraction of wood associated with heating and cooling - a phenomenon called hygrothermal recovery (Kubler 1987). Tangential dimensional change in the wood is the most important driver of log-end splitting as it is far greater than radial and longitudinal dimensional changes (Kubler 1987; Marchal et al. 1993). The 
magnitude of split propagation within a log depends not only on the inherent growth stresses but also on the temperature and duration of heating (Marchal et al. 1993; Gril and Thibaut 1994; Becker and Beimgraben 2002; Dupleix et al. 2012).

The present study aimed to evaluate the relative importance of the above factors on the magnitude of log-end splitting using Tasmanian plantations of Eucalyptus nitens (Deane and Maiden) Maiden. Plantation-grown trees of this species can produce log-end splits when felled and crosscut into logs (Blackburn et al. 2011; Valencia et al. 2011). $E$. nitens is widely planted in temperate regions of the world (Hamilton et al. 2011) and is the second most prevalent hardwood plantation species in Australia (Gavran 2014). Within Tasmania, there are approximately 208, 400 ha of E. nitens plantations (Hamilton et al. 2008; Gavran 2014) which are mainly managed for pulpwood. Fifteen percent of these plantations, however, have been pruned and thinned to produce high-quality logs for sawing and/or veneer production (Forestry Tasmania 2011). It is anticipated that these pruned and thinned plantations will be used by Tasmania's forest processing industries along with traditional sources of hardwood logs from the island's native forests (Forestry Tasmania 2011).

A few studies have investigated factors affecting log-end splitting or growth stresses in E. nitens. With respect to genetic factors, Blackburn et al. (2011) showed that trees grown in a Tasmanian trial of families from different geographic races exhibited significant genetic variation in logend splitting within the races. However, no significant genetic difference has been reported between races of this species (Blackburn et al. 2011). In terms of silviculture, Valencia et al. (2011) showed that thinning to different spacings did not affect log-end splitting after accounting for the positive effect of stem diameter. Several recent studies of Tasmanian E. nitens have shown log-end splitting increases with height up the tree (Blackburn, Hamilton et al. 2011; Valencia et al. 2011). We are not aware of any previous studies investigating the effect of post-felling treatments, such as storage and steaming on log-end splitting for E. nitens.

The specific objective of this study is to quantify the development of log-end splitting in plantation-grown $E$. nitens and determine the influence of:

- Site, log position, diameter and inter-tree competition

- Log storage time

- A pre-peeling steam treatment

Improved understanding of the factors that determine logend splitting will contribute to improved use of the $E$. nitens plantation resource and ultimately to more effective forest management.

\section{Materials and methods}

\subsection{Field sites and tree selection}

Three contrasting E. nitens plantations at Strathblane, Geeveston and Florentine in the south of Tasmania (Australia) were selected for this study (Table 1). These E. nitens sites belong to Forestry Tasmania and were previously included in multi-species studies of veneer recovery and quality (Hamilton et al. 2014; McGavin et al. 2014). They encompassed different silvicultural treatments and/or site productivities: Strathblane and Geeveston were thinned and pruned for solid wood production but differed markedly in productivity. The Florentine site was an unthinned and unpruned pulpwood stand. Within each site, a measurement plot (972.3 to $2156 \mathrm{~m}^{2}$ ) was established, and basal area within plots was determined. Trees for felling were then selected at random within plots, excluding trees of less than 220 or greater than $390 \mathrm{~mm}$ in diameter breast height over bark (DBH; $1.3 \mathrm{~m}$ ) or with any evident visual defects such as double leaders. At the Geeveston site, no maximum DBH criterion was applied as trees were too large and a representative sample could not be obtained within these log size constraints. Following Medhurst et al. (2012), intra-specific competition for each tree was quantified as the sum of the basal areas of competing trees located within a 6-m radius of each sampled tree.

\subsection{Preparation and log measurement}

All trees were manually felled by the same operator, and height was measured from the felled tree. Two 2-m logs were cut from each tree. The lower log started at $0.5 \mathrm{~m}$ and the upper log at $3.9 \mathrm{~m}$ above ground level. Logs were transported to a local storage facility at Geeveston on the same day as felling, where they were debarked and measured. Small end diameter under bark (SEDUB) and large end diameter under bark (LEDUB) were assessed on each log using a diameter tape. The length of log-end splits were measured on each log end as well as the length of split on the log surface. Log-end splitting was evaluated with two indices, Split Index-2 (SI-2) and maximum split length on the log surface. Split Index-2 is described by Yang (2005) and integrates all splits present in the log, weighted by the mean radius of the log. The maximum split length was evaluated across either end of the log. After measurement, $\log$ ends were sprayed with sealant (Dussek-Campbell TM) to minimise moisture loss. Logs were then stacked in a shipping container for transport to a research-scale peeling plant at Salisbury, Queensland. To minimise drying, logs were sprayed with water prior to transport in the shipping container and while in storage at Salisbury. 
Table 1 Characteristics of the three E. nitens plantations sampled

\begin{tabular}{|c|c|c|c|}
\hline Sites & Strathblane & Geeveston & Florentine \\
\hline \multicolumn{4}{|l|}{ Location and environment } \\
\hline Latitude and longitude $\left({ }^{\circ}\right)$ & $-43.38 ; 146.94$ & $-43.15 ; 146.84$ & $-42.66 ; 146.47$ \\
\hline pMAI $\left(\mathrm{m}^{3} / \text { ha } / \text { year }\right)^{\mathrm{a}}$ & 20.8 & 36.6 & 37.2 \\
\hline Site index & 22.7 & 30.3 & 30.5 \\
\hline Altitude (metres above sea level) & 153 & 296 & 438 \\
\hline Annual mean temperature $\left(^{\circ}\right)$ & 10.9 & 10.3 & 9.5 \\
\hline Minimum temperature coolest month $\left(^{\circ}\right)$ & 3.4 & 2.2 & 1.2 \\
\hline Annual rainfall $(\mathrm{mm})$ & 1161 & 1212 & 1436 \\
\hline Annual evaporation (mm) & 963 & 929 & 913 \\
\hline Soil description & Sandy over clayey & Loamy over clayey & Yellow podzolic (gradational) \\
\hline Soil profile & $\begin{array}{l}\text { Triassic sandstone-sandy } \\
\text { over clayey soil }\end{array}$ & $\begin{array}{l}\text { Red to brown clayey soils-Jurassic } \\
\text { dolerite and Quaternary } \\
\text { dolerite talus }\end{array}$ & $\begin{array}{l}\text { Yellowish brown clay-mudstone, } \\
\text { brown kurosol }\end{array}$ \\
\hline Wind direction & $\begin{array}{l}\text { Generally northwest and site } \\
\text { has intermediate exposure }\end{array}$ & $\begin{array}{l}\text { Generally northwest and site } \\
\text { is exposed }\end{array}$ & $\begin{array}{l}\text { Generally southwest and the site } \\
\text { has intermediate exposure }\end{array}$ \\
\hline \multicolumn{4}{|l|}{ Silviculture } \\
\hline Year of establishment & 1993 & 1991 & 1993 \\
\hline Genetic origin & $\mathrm{n} / \mathrm{a}$ & $\mathrm{n} / \mathrm{a}$ & $\mathrm{n} / \mathrm{a}$ \\
\hline Management & Thinned and pruned & Thinned and pruned & Pulp \\
\hline $\begin{array}{l}\text { Establishment spacing } \\
\text { (tree by row in metres) }\end{array}$ & 2 by 4 & 2.5 by 3 & 2 by 4 \\
\hline $\begin{array}{l}\text { Establishment density } \\
\left(\text { stems } \mathrm{ha}^{-1}\right)\end{array}$ & 1250 & 1334 & 1250 \\
\hline $\begin{array}{l}\text { Age at thinning } \\
\left(\text { retained stems ha }{ }^{-1}\right)\end{array}$ & $11(300)$ & $10(192)$ & Unthinned \\
\hline Age at pruning (height, m) & 3 (unknown) and 5 (6 m) & 4 (unknown) and 6 (6 m) & Unpruned \\
\hline \multicolumn{4}{|l|}{ Harvest characteristics plot-level data } \\
\hline Felling age (years) & 20 & 22 & 20 \\
\hline Harvest stocking (stems ha ${ }^{-1}$ ) & 292 & 196 & 669 \\
\hline $\mathrm{DBH}^{\mathrm{b}}(\mathrm{cm})$ & 31.2 & 43.1 & 26.9 \\
\hline Basal area $\left(\mathrm{m}^{2} \mathrm{ha}^{-1}\right)$ & 23.2 & 30.3 & 41.3 \\
\hline \multicolumn{4}{|l|}{ Selected trees } \\
\hline $\mathrm{DBH}^{\mathrm{b}}(\mathrm{cm})$ & 30.0 & 42.7 & 33.9 \\
\hline Height (m) & 26.9 & 37.5 & 36.4 \\
\hline Slenderness ${ }^{\mathrm{c}}$ & 90.5 & 92.0 & 107.8 \\
\hline Mean log diameter $(\mathrm{cm})$-lower & 27.2 & 39.3 & 32.3 \\
\hline Mean log diameter $(\mathrm{cm})$ - upper & 23.1 & 35.8 & 29.3 \\
\hline
\end{tabular}

${ }^{\text {a }}$ Peak mean annual increment

${ }^{\mathrm{b}}$ Diameter at breast height over bark

${ }^{\mathrm{c}}$ Height/DBH

\subsection{Assessments}

Log-end split evaluations were made three times (Fig. 1). The first was $24 \mathrm{~h}$ after the trees were harvested, hereafter referred to as the 'post-felling' assessment. The second was during 2 days, starting on the day after the logs arrived at the peeling plant (13 and 14 days after the harvest) and is hereafter referred to as the 'log-yard' assessment. The third ('predocking') assessment was undertaken just before peeling.
Logs from the Geeveston site were not included in the third assessment as a number of logs were too large for peeling in Salisbury research facilities and were moved to a nearby commercial facility for peeling. The remaining logs (Strathblane and Florentine) were allocated to one of two groups - steamed or not steamed (31 logs per group). One log from each tree was randomly allocated to each group. The steaming treatment is described by McGavin et al. (2014). Briefly, prior to peeling, 2-m logs were steamed in batches of (usually) six 
Fig. 1 The sequence of assessments undertaken according to days from harvest. Photographs show the development of log-end splitting in each assessment for a log exhibiting high splitting. The $\log$ was from the Florentine site and was steamed. The maximum surface split (Max-split, mm) and split index $2(S I-2)$ for each assessment are indicated
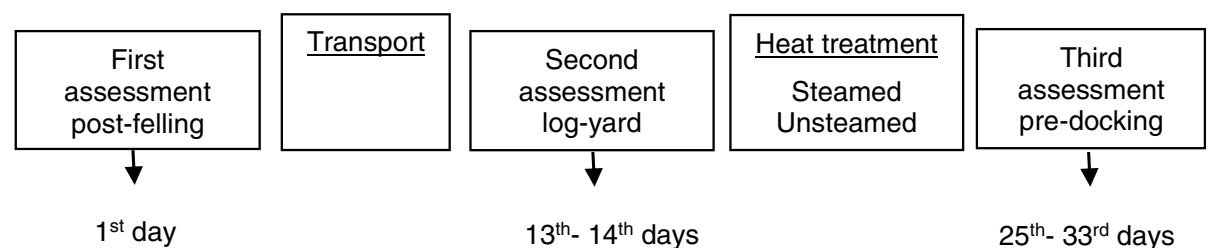

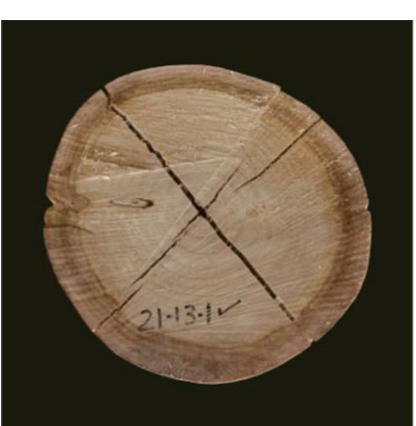

Max-split: 330

SI-2: 9.0

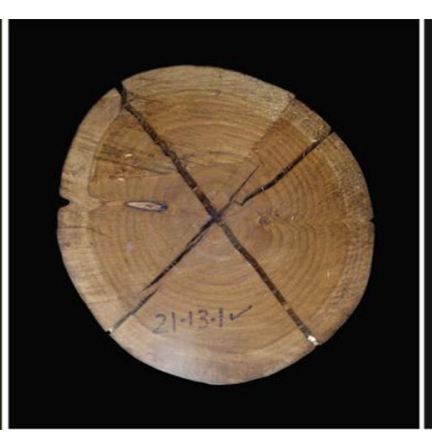

Max-split: 395

SI-2:14.1

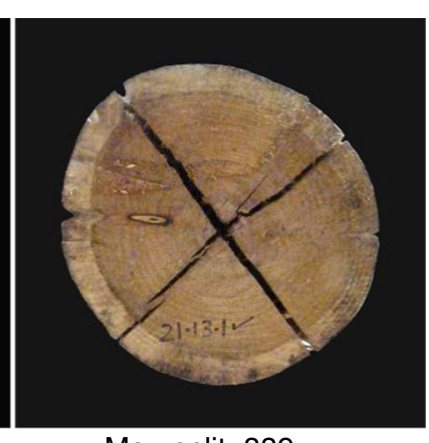

Max-split: 889 randomly chosen logs, with all batches processed over a period of seven working days (25-33 days after harvest). The logs were heated with saturated steam at $80^{\circ} \mathrm{C}$ for approximately $8 \mathrm{~h}$. Generally, six randomly selected steamed logs and six unsteamed logs were peeled each day. The pre-docking assessment was undertaken immediately after the steam treatment, but in this case only the maximum split length on the log surface was assessed to avoid temperature loss prior to log peeling. The same evaluation was made on the sample of unsteamed logs being processed on the same day.

\subsection{Data analysis}

Both splitting measures were log-transformed $\left(\log _{10}[x+1]\right)$ for analysis as preliminary analyses of raw log-level data revealed that the distribution of residuals were neither normal nor homoscedastic.

Models involving various combinations of site, assessment time, log position and covariates were fitted to the splitting data using a restricted maximum likelihood approach implemented with the PROC MIXED procedure of SAS ${ }^{\mathrm{TM}}$ (Version 9.2, SAS Institute, Cary, NC, USA). Fixed effects were tested using Type III F tests.

Repeated-measures models (Wolfinger and Chang 1995) were used when fitting assessment time or log position, with tree as the subject.

Specific models fitted to the pre-steaming splitting data were based on tree-level (average of both logs) or log-level data and included:

(a) A repeated-measures model fitting site (three fixed levels), assessment time (two fixed levels) and their interaction (six fixed levels) to the tree-level data, with tree as the subject (b) A repeated-measures model fitting site (three fixed levels), log position (two fixed levels) and their interaction (six fixed levels) to the log-level data, with tree as the subject

To examine the effect of intra-specific competition for each tree (surrounding basal area) and focal tree DBH and slenderness (height/DBH) on log-end splitting, a fixed effects model as previously described was fitted to the treelevel data that also include basal area of surrounding trees as well as DBH or slenderness of the focal tree and their interaction as covariates.

In addition to the fixed explanatory variables mentioned above, the same type of model was fitted to determine the influence of the time between first and second assessments.

\section{Results}

\subsection{Site differences and storage}

Analysis of the tree-level SI-2 data revealed that log-end splitting significantly increased between the post-felling and logyard assessments (time $F_{1,39}=123.6, P<0.001$; Fig. 2a). Over this period, the average SI-2 increased by $96.6 \%$. This increase was not significantly different between sites (site $\times$ time $\left.F_{2,39}=0.5, P \geq 0.05\right)$; however, the sites themselves differed significantly (site $F_{2,39}=12.1, P<0.001$ ). Log-end splitting was lowest in logs from the low-altitude, low-productivity site at Strathblane which had been thinned and pruned and greatest in the logs from the thinned and pruned, mid-altitude, highproductivity site at Geeveston (Fig. 2a). These temporal and site differences were evident whether splitting was assessed 
$\mathbf{a}$
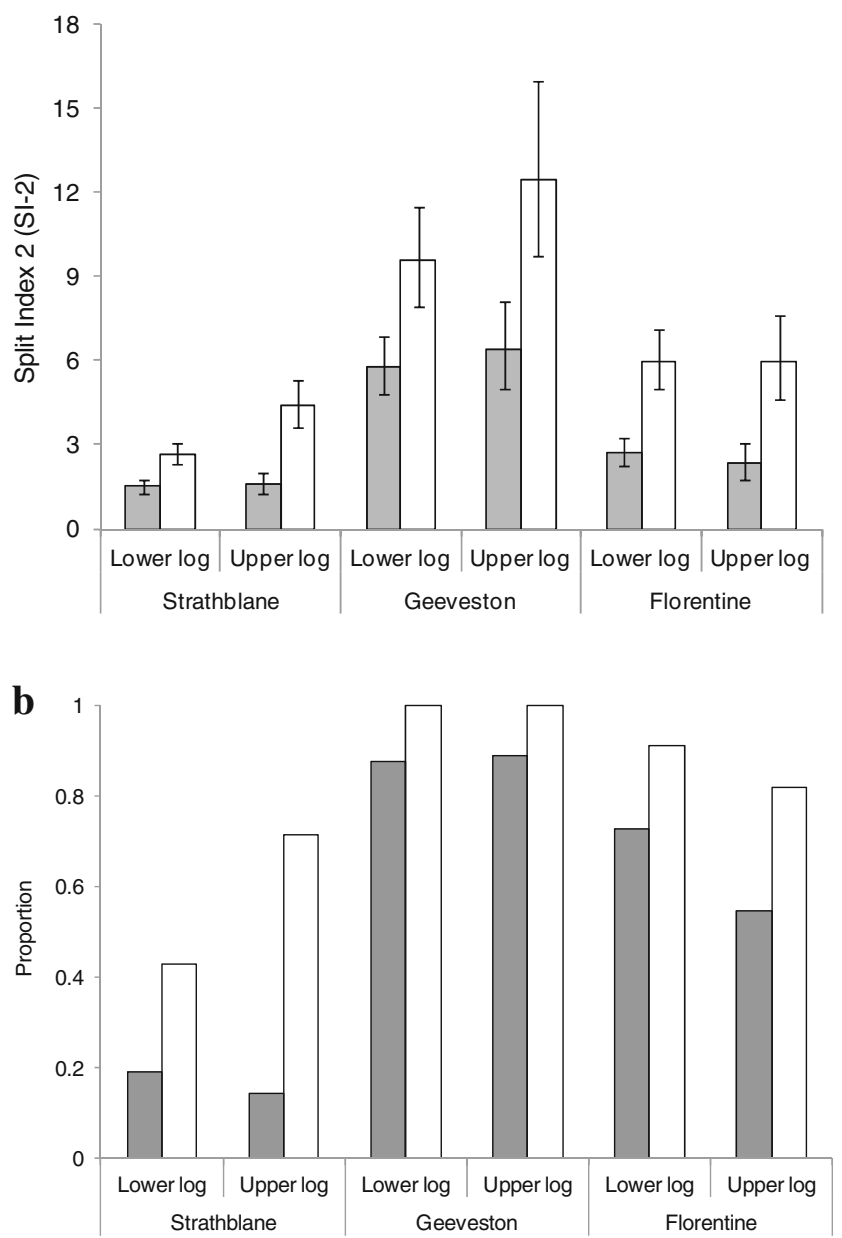

Fig. 2 Site by $\log$ position. a Least squares mean ( \pm s.e.) Split index 2 (SI-2) following back-transformation and $\mathbf{b}$ the proportion of logs with surface splits. The post-felling (grey) and the log-yard (white) assessments are shown for upper and lower logs for each site

using SI-2 (Fig. 2a) or as a percentage of logs showing surface splits (Fig. 2b). Site differences were also clearly evident when log-level data were analysed at separate assessment times and evident in the upper or lower log (Table 2; Fig. 2).

While there was no significant difference in SI-2 between upper and lower logs immediately following harvesting (postfelling), differences in SI-2 did become evident with time after transport and storage (Table 2). Between the post-felling and log-yard assessments, SI-2 of the upper logs increased $141 \%$ and the lower logs increased $88 \%$.

The site $\times \log$ position interaction was not statistically significant (Table 2). Nevertheless, the increased splitting in upper logs following storage (post-felling versus log-yard assessments) was most evident in trees from the two pruned and thinned sites (Strathblane and Geeveston; Fig. 2a). At this stage, all logs from Geeveston had surface splits, but for Strathblane only $43 \%$ of the lower logs had surface splits compared with $71 \%$ of the upper logs (Fig. 2b).
Table 2 Significance of site and log position on log-end splitting (SI-2) at post-felling and log-yard assessments. The $F$ values and their significance for each assessment are shown. A repeated-measures model was fitted to log-level means with site $(n d f=2), \log$ position $(n d f=1)$ and their interaction fitted as fixed terms. The denominator degrees of freedom range from 38 to 40

\begin{tabular}{lll}
\hline Fixed terms & $F$ value & \\
\cline { 2 - 3 } & Post-felling & Log-yard \\
\hline Site & $13.4^{* * *}$ & $10.4^{* * * *}$ \\
Log position & $0.0 \mathrm{~ns}$ & $6.7^{*}$ \\
Site $\times \log$ position & $0.5 \mathrm{~ns}$ & $2.4 \mathrm{~ns}$ \\
\hline
\end{tabular}

ns not significant

$* P<0.05 ; * * P<0.01 ; * * * P<0.001$

\subsection{Silviculture differences}

Despite the fact that sites differed markedly in the competitive environment and DBH of felled trees (Table 1), these factors did not completely explain the significance of the effect of site-of-origin on log-end splitting. When it was tested as a covariate in a tree-level model which included site and interaction terms, the competitive environment of a tree had no significant effect on SI-2. This was the case for both the main covariate effect and its interaction with site post-felling $\left(F_{1}\right.$, ${ }_{30}=0.28, P \geq 0.05$; interaction with site $F_{2,30}=0.19, P \geq 0.05$ ) and in the log-yard $\left(F_{1,30}=0.29, P \geq 0.05\right.$; interaction with site $F_{2,30}=0.31, P \geq 0.05$ ). Dropping the competition covariate and its interaction with site and fitting a reduced model revealed that standing-tree DBH significantly affected splitting. However, this relationship was site dependent, with a significant $\mathrm{DBH} \times$ site interaction for both post-felling and log-yard SI-2 (Table 3). This interaction was due to a significant positive relationship between SI-2 and DBH at the high-altitude Florentine site which was unpruned and unthinned (post-felling $R^{2}=59.8 \%, P<0.01 ; \log$-yard $\left.R^{2}=50.7 \%, P<0.05\right)$. However, at the two pruned and thinned sites, DBH did not explain

Table 3 Significance of site and diameter at breast height over bark on log-end splitting (SI-2) at post-felling and log-yard assessments. The $F$ values and their significance for each assessment are shown. The model was fitted to tree level means with site $(n d f=2)$ as a fixed effect and DBH as a covariate $(n d f=1)$. The denominator degrees of freedom for all terms is 36

\begin{tabular}{lll}
\hline Fixed terms & \multicolumn{2}{l}{ value } \\
\cline { 2 - 3 } & Post-felling & Log-yard \\
\hline DBH & $11.5^{*}$ & $5.8^{*}$ \\
Site & $5.0^{*}$ & $4.8^{*}$ \\
DBH $\times$ site & $4.3^{*}$ & $4.8^{*}$ \\
\hline
\end{tabular}

ns not significant

$* P<0.05 ; * * P<0.01$; *** $P<0.001$ 
significant variation in SI-2 amongst trees (Strathblane, postfelling $R^{2}=3.7 \%, P=0.404$, log-yard $R^{2}=0.4 \%, p=0.785$; Geeveston, post-felling $R^{2}=7.3 \%, P=0.449$; $\log$-yard $R^{2}=$ $0.09 \%, P=0.0933$. Even when accounting for tree $\mathrm{DBH}$ and its interaction, there still remained a significant main effect of site on SI-2 (Table 3). Similar conclusions are reached when fitting tree height which was slightly more strongly associated with the splitting index than $\mathrm{DBH}$, with the exception of the post-felling splitting index where the significance of the site effect was reduced slightly $(P<0.1)$. Tree slenderness had no significant $(P>0.05)$ effect on the post-felling or log-yard splitting in any model.

\subsection{Steam treatment}

As a consequence of time constraints imposed by veneer processing, the evaluation of the effect of steaming on splitting was conducted based on the maximum surface split length of each log rather than SI-2. However, maximum surface split length and SI-2 of logs were positively associated (Fig. 3). There was no significant difference in maximum surface split length on logs treated with steam compared with those not treated (Table 4). The differences in splitting between samples were simply an extension of pre-steaming storage effects, as were the slight increases between the log-yard and predocking assessments (Figs. 4 and 5). Despite the fact that only logs from the least differentiated sites (Strathblane and Florentine) were being studied, site-of-origin effects were still evident in steamed and unsteamed treatments prior to docking (Table 4; Figs. 4 and 5).

\section{Discussion}

A key finding of this study was the identification of site-oforigin as being an important factor contributing to variation in the log-end splitting of these plantation-grown trees of a single

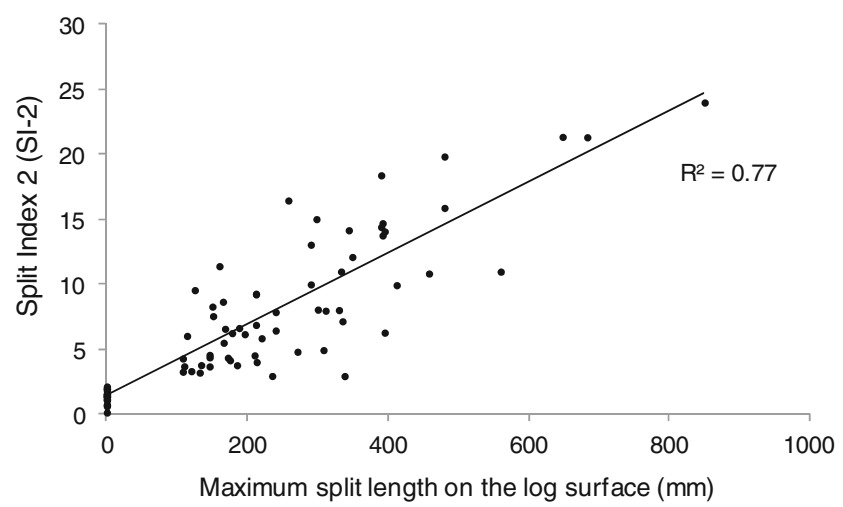

Fig. 3 Linear regression analysis between split index 2 and the maximum split length on the log surface as assessed in the log-yard (without the zero values in maximum split length $R^{2}=0.64$ )
Table 4 Significance of factors affecting maximum surface splitting in the pre-docking assessment. A repeated-measures model was fitted to log-level data with site, log position, steam treatment and their interaction fitted as fixed terms. The $F_{1,54}$ values and their significance for each assessment are shown. Data are from the Strathblane and Florentine sites only

\begin{tabular}{ll}
\hline Fixed terms & $F$ value \\
\hline Site & $6.9^{*}$ \\
Log position & $0.4 \mathrm{~ns}$ \\
Site $\times \log$ position & $1.5 \mathrm{~ns}$ \\
Steam treatment & $0.1 \mathrm{~ns}$ \\
Steam treatment $\times$ site & $0.1 \mathrm{~ns}$ \\
Steam treatment $\times \log$ position & $0.6 \mathrm{~ns}$ \\
Steam treatment $\times$ site $\times \log$ position & $2.9 \mathrm{~ns}$ \\
\hline
\end{tabular}

ns not significant

$* P<0.05 ; * * P<0.01 ; * * * P<0.001$

species. This effect was evident immediately after felling in both upper and lower logs and was maintained along the processing chain and still evident after accounting for variation in DBH. The site mean SI-2 values differed by up to $39.3 \%$ depending upon log storage time and position, and the values of our least split sites were most comparable with the site mean reported by Valencia et al. (2011) for 22-year-old $E$. nitens grown in northeast Tasmania. The exact causal factor(s) underlying these site differences can only be speculated as there are clearly both environmental and silvicultural differences amongst these sites. In addition, the possibility of differences in log-end splitting due to genetic stock cannot be dismissed. However, most Tasmanian E. nitens plantations established approximately 20 years ago were established from open-pollinated seed from Central Victoria (Hamilton and Potts 2008), and genetic differences due to race of origin are unlikely as no race differences within this region were detected in an E. nitens genetic trial grown in Tasmania (Blackburn et al. 2011).

Our study included both thinned (and pruned) and unthinned plantation sites, but these differences alone are unlikely to explain the site differences that we observed for several reasons. Firstly, no significant effect of thinning per se on log-end splitting has been reported in an E. nitens thinning trial (Valencia et al. 2011). Secondly, within sites, there is no significant effect of standing local competition at the time of harvest on log-end splitting (present study) or indirect measures of growth stress (Valencia et al. 2011), although the influence of the competitive environment at earlier ages cannot be dismissed (Biechele et al. 2009). Finally, although there are only slight differences in the age of thinning and pruning, there is a significant difference between the two thinned sites, with the logs from the Geeveston site having significantly greater log-end splitting than those from the Strathblane site. Of the environmental factors which differ between Strathblane 
Fig. 4 Development of maximum split length on the log surface (Max-split, mm) of the steamed and unsteamed log samples from Strathblane and Florentine. Back-transformed least square mean values are shown for the three assessments (post-felling, log-yard, predocking). Steaming occurred just before the pre-docking assessment. Common letters indicate means where the pairwise LSD is not significantly different at the 0.05 level

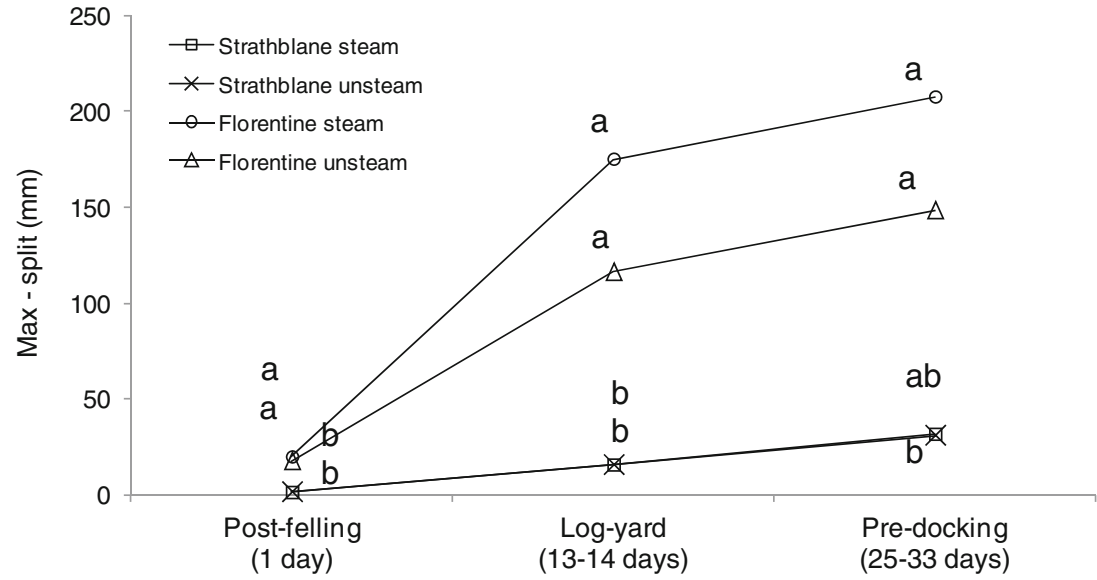

and Geeveston, greater exposure to prevailing winds is a possible explanation of the greater splitting in logs from Geeveston, especially when coupled with higher site productivity and late thinning when 10 years old (Malan 1995). Wind can produce high growth stress (as measured indirectly from peripheral longitudinal growth strain) on the leeward side of E. nitens trees (Valencia et al. 2011) and can also result in an asymmetrical crown that may further increase growth stresses (Becker and Beimgraben 2002). A positive relationship between growth stress and tree slenderness has been reported in Fagus sylvatica (Jullien et al. 2013). However, this species has quite different architecture to $E$. nitens being twofold less slender, and the variation among trees in slenderness was unrelated to log-end splitting in the case of E. nitens.

Our finding that log-end splitting in $E$. nitens significantly increased with increasing height up the stem was consistent with that found by Valencia et al. (2011) for Tasmanian-grown E. nitens, although in their case the difference was manifested immediately after felling. The trend for log-end splitting to increase with tree height in thinned (and pruned) plantations

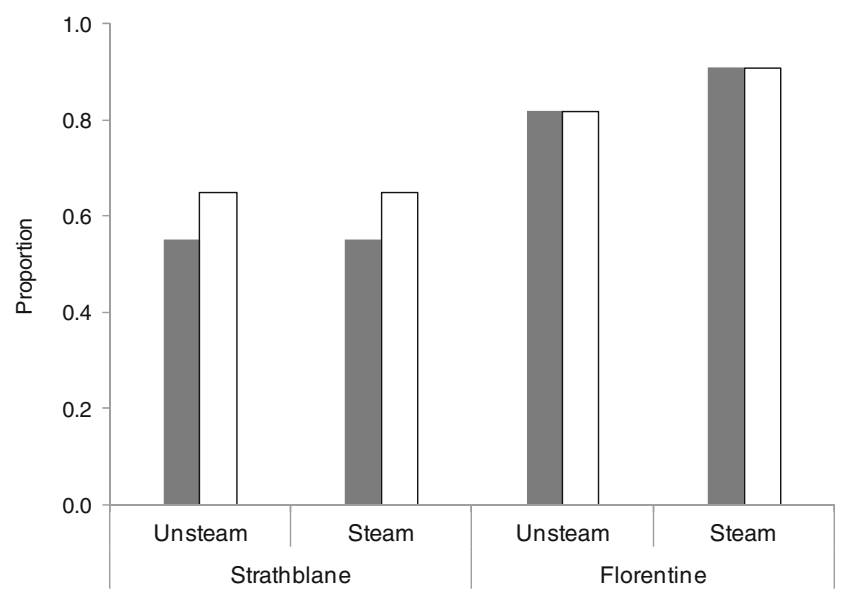

Fig. 5 The proportion of steamed and unsteamed logs from the Strathblane and Florentine sites with surface splits in the log-yard (grey) and in the pre-docking assessment (white) undertaken after steaming is contrary to the expectation based on DBH as the smaller upper logs split more than the larger lower logs. Valencia et al. (2011) suggest that this trend may be due to a greater level of growth stress at greater heights. Consistent with this hypothesis, based on studies of several eucalypt clones, Baillères (1994) reported that peripheral longitudinal growth stress tends to increase in the vicinity of living branches and is higher close to the crown, allowing the tree a more efficient control of the crown position. Valencia et al. (2011) also raised the possibility that the greater log-end splitting that they observed in the upper log could be due to the greater bending of the upper part of the tree during mechanical harvesting. However, the present study suggests that this is not a contributing factor as, firstly, our trees were not mechanically harvested and, secondly, the difference between the upper and lower $\log$ tended to increase with storage time.

Storage is a key phase in the processing industry, and various approaches have been adopted by processors in an effort to minimize log-end splitting during this period, including the application of a log-end sealer, the use of sprinklers in logyards to keep logs moist and debarking just after steaming and peeling (Chauhan et al. 2006). While our scoring times do not allow finer resolution of this first period, on sites prone to logend splitting, there is clearly a rapid early increase in splitting despite the application of a log-end sealer and water to minimise moisture loss. Log-end splitting was similar between lower and upper logs $24 \mathrm{~h}$ after cross-cutting but became greater in the upper log with storage time. Delayed release of strain may explain the later appearance of a significant difference in splitting between upper and lower logs (Kubler 1987). The increased splitting of upper logs over time could be indicative of higher, longer-lasting compression forces on the upper log wood than on the wood of the lower log, which require more time to release. Boyd and Schuster (1972) found that full release of growth stresses may take two or even 3 weeks, as did Malan (1995) with Eucalyptus.

The general two-phase split development described previously (Priest et al. 1982; Bariska 1992) was evident in this trial 
with log-end split development being most rapid between the post-felling and log-yard assessment (13-14 days) and slower between log-yard and pre-docking assessments (12-19 days). The increase in splitting during storage may be due to the delayed release of growth stress as is suggested by Bariska (1992), possibly from a time effect on viscoelasticity properties of green wood (Gril and Thibaut 1994).

The steam heating of logs prior to peeling is a standard practice in the veneer industry because it improves both the yield and quality of veneer (Dupleix et al. 2012). However, steaming may release growth stresses (Severo et al. 2010) and potentially promote log-end splitting (Baldwin 1995). This effect was not observed in the present study. This is likely due to the fact that logs had an extended storage time, meaning that most of release of growth strain in the logs had been completed prior to steaming. However, as the temperature used to heat the logs was lower than is recommended by Dupleix et al. (2012) and Severo et al. (2010), we cannot dismiss the possibility that further splitting may have occurred if higher temperatures had been used.

Our demonstration of a relationship between the more detailed split index SI-2 and the quickly assessed maximum split length on the log surface, as previously reported for eucalypts (Bariska 1990), allowed assessment of the change in log-end splitting during log processing for veneer-following steaming and just prior to docking. However, the impact of the various values of SI-2 and the maximum surface split on the veneer recovery needs further study. While Hamilton et al. (2014) did not detect an effect of post-felling SI-2 values on green recovery following docking of these logs for spindleless lathe peeling, this may be more evident later as splitting increases with storage and will depend upon the opportunities for docking of logs prior to peeling. Although logs with lower SI-2 values (less than 3.0) do not have surface splits (Fig. 3), this does not exclude the possibility that splitting at this level could still reduce veneer recovery in addition to reducing the grade recovery (McGavin et al. 2014). This is because SI-2 assumes that the split shape is an isosceles right-angled triangle which is projected inside the log (Yang 2005). Such splitting would extend most into the residual billet core (target radius of $25 \mathrm{~mm}$ in Hamilton et al. (2014)), and splitting outside of this could be managed to some extent depending upon the opportunities for docking.

\section{Conclusion}

The site-of-origin was a key factor influencing variation in log-end splitting and was constant across all storage and steam treatments. The exact causal factor(s) underlying these site differences can only be speculated as there are clearly environmental and silvicultural differences amongst these sites. Nevertheless, our study highlights that not only do sites differ in their mean log-end splitting but also they may differ in the way that splitting develops with storage and the association of splitting with tree size. Storage increased the severity of logend splitting in all logs, but the greatest increase in splitting was observed in upper logs, possibly due to a change in growth stress with tree height. Steam treatment did not affect the severity of splitting, but this may be due to extended storage times. The maximum surface split length was a good index to evaluate the steam treatment effect on log-end splitting due to its ease of assessment and strong association with more complex indexes. Further research is necessary for a better understanding of the intensity of log-end splitting with respect to environmental and silviculture factors and their interaction with storage and steam treatment in order to minimize log-end splitting in commercial veneer production through site selection and/or silviculture.

Acknowledgments We acknowledge Forestry Tasmania (FT) and Paul Adams for assistance in project planning, access to sites, the provision of trees and staff, tree felling and log transport; Island Specialty Timbers (IST) for use of their log-yards and log handling; and Austral Plywoods for peeling large-diameter logs. Specifically, we thank Mark Hunt (NCFFI and UTAS), Chris Emmett (IST); Peter Wass, Crispen Marunda, Kristen Dransfield, Matt McCormic, Mitchell Fulford, Rowan Eiszele, Shane Burgess (FT); Chris Harwood (CSIRO) and staff at the Queensland Department of Agriculture, Fisheries and Forestry Salisbury Research Centre for their technical and/or professional assistance.

Funding This work was supported by a Ph.D. scholarship (MV) from the Chilean BecasChile Program and a top-up from the Australian Cooperative Research Centre for Forestry. We also thank the National Centre for Future Forest Industries (NCFFI) at the University of Tasmania for research funding.

\section{References}

Archer R (1987) Growth stresses and strains in trees. Springer, Berlin Heidelberg

Baillères H (1994) Précontraintes de croissance et propriétés mécanophysiques de clones d'eucalyptus (Pointe-Noire, Congo): hétérogénéités, corrélations et interprétations histologiques, Université de Bordeaux I

Baldwin RF (1995) Peeler block preconditioning. In: Baldwin RF (ed) Plywood and veneer-based products: manufacturing practices. Miller Freeman Books, San Francisco, CA, pp 112-130

Bariska M (1990) Growth stress splits in eucalypt mining timber. IAWAIUFRO wood anatomy symposium. IAWA Bulletin, Zurich, Switzerland, p 115

Bariska M (1992) Collapse phenomena in eucalypts. Wood Sci 26:165179

Barros E, Verryn S, Hettasch M (2002) Identification of PCR-based markers linked to wood splitting in Eucalyptus grandis. Ann For Sci 59:675-678. doi:10.1051/forest:2002055

Becker G, Beimgraben T (2002) Occurrence and relevance of growth stresses in beech (Fagus sylvatica L.) in central Europe, final report of FAIR-project CT 98-3606. Institut für Fostbenutzung und Forstliche Arbeitswissenschaft, Albert-Ludwigs-Universität Freiburg Freiburg, Germany, p 323 
Biechele T, Nutto L, Becker G (2009) Growth strain in Eucalyptus nitens at different stages of development. Silva Fenn 43:669-679

Blackburn DP, Hamilton MG, Harwood CE, Innes TC, Potts BM, Williams D (2011) Genetic variation in traits affecting sawn timber recovery in plantation grown Eucalyptus nitens. Ann For Sci 68: 1187-1195. doi:10.1007/s13595-011-0130-y

Boyd JD, Schuster KB (1972) Tree growth stresses 4. Viscoelastic strain recovery. Wood Sci Technol 6:95-120

Chauhan S, Donnelly KB, Huang C, Nakada R, Yafang Y, Walker J (2006) Wood quality: multifaceted opportunities. In: Walker J (ed) Primary wood processing: principles and practice, 2nd edn. Springer, Dordrecht, Netherlands, pp 159-202

Dupleix A, Denaud LE, Bleron L, Marchal R, Hughes M (2012) The effect of log heating temperature on the peeling process and veneer quality: beech, birch, and spruce case studies. Eur J Wood Wood Prod 71:163-171. doi:10.1007/s00107-012-0656-1

FAO (2005) The potential for fast-growing commercial forest plantations to supply high value roundwood. Working paper FP/33. In: James R, Del Lungo A (eds) Planted forests and trees working papers. Forest Resources Development Service, Forest Resources Division. FAO, Rome, Italy

Forestry Tasmania (2011) Evaluation of wood resource scenarios relevant to the Tasmanian forests statement of principles to lead to an agreement-final report to signatories. Forestry Tasmania, HobartAustralia

Gavran M (2014) Australian plantation statistics 2014 update. Technical report 14.2. In: ABARES (ed) Camberra-Australia

Gril J, Thibaut B (1994) Tree mechanics and wood mechanics - relating hygrothermal recovery of green wood to the maturation process. Ann Sci For 51:329-338. doi:10.1051/forest:19940311

Hamilton MG, Potts BM (2008) Review of Eucalyptus nitens genetic parameters. N Z J For Sci 38:102-119

Hamilton MG, Joyce K, Williams D, Dutkowski G, Potts BM (2008) Achievements in forest tree improvement in Australian and New Zealand. 9. Genetic improvement of Eucalyptus nitens in Australia. Aust For 71:82-93

Hamilton MG, Dutkowski GW, Joyce KR, Potts BM (2011) Metaanalysis of racial variation in Eucalyptus nitens and E. denticulata. N Z J For Sci 41:217-230

Hamilton MG, Blackburn DP, McGavin RL, Baillères H, Vega M, Potts BM (2014) Factors affecting log traits and green rotary-peeled veneer recovery from temperate eucalypt plantations. Ann For Sci. doi: 10.1007/s13595-014-0430-0

Iglesias-Trabado G, Wilstermann D (2009) Eucalyptus universalis. Global cultivated eucalypt forests map 2009. version 1.0.2 www. git-forestry.com. Accessed: 1 Dec 2014

Jullien D, Laghdir A, Gril J (2003) Modelling log-end cracks due to growth stresses: calculation of the elastic energy release rate. Holzforschung 57:407-414. doi:10.1515/hf.2003.060

Jullien D, Widmann R, Loup C, Thibaut B (2013) Relationship between tree morphology and growth stress in mature European beech stands. Ann For Sci 70:133-142. doi:10.1007/s13595-012-0247-7

Kubler H (1987) Growth stresses in trees and related wood properties. For Abs 48:131-189
Kubler H (1988) Silvicultural control of mechanical stresses in trees. Can J For Res 18:1215-1225. doi:10.1139/X88-188

Malan FS (1995) Eucalyptus improvement for lumber production. Seminário Internacional de Utilização da Madeira de Eucalipto para Serraria. Instituto de Pesquisas e Estudos Florestais, Sao PauloBrazil, pp 1-19

Malan FS, Verryn SD (1996) Effect of genotype-by-environment interaction on the wood properties and qualities of four-year-old Eucalyptus grandis and E. grandis hybrids. Sout Afri For J,47-53

Marchal R, Jullien D, Mothe F, Thibaut B (1993) Mechanical aspects of heating wood in rotary veneer cutting. 11th International Wood Machining Seminar, Honne-Norway, pp. 257-278

Mattheck C, Kubler H (1997) Growth stresses. In: Mattheck C, Kubler H (eds) Wood - the internal optimization of trees. Springer, Berlin Heidelberg, pp 63-89

McGavin RL, Bailleres H, Lane F, Blackburn D, Vega M, Ozarska B (2014) Veneer recovery analysis of plantation eucalypt species using spindleless lathe technology. Bioresources 9:613-627

Medhurst J, Downes G, Ottenschlaeger M, Harwood C, Evans R, Beadle C (2012) Intra-specific competition and the radial development of wood density, microfibril angle and modulus of elasticity in plantation-grown Eucalyptus nitens. Trees 26:1771-1780. doi:10. 1007/s00468-012-0746-z

Nixon K (1991) A test of fifteen Eucalyptus species and provenances on two sites in Natal-some bark and timber characteristics. In: Schonau APG (ed) Symposium on intensive forestry: the role of Eucalyptus. IUFRO- P2.02-01 Productivity of Eucalyptus, Durban, South Africa, pp. 258-265

Okuyama T (1997) Assessment of growth stresses and peripheral strain in standing trees. IUFRO conference on silviculture and improvement of eucalypts V3: silviculture, productivity and utilization of eucalypts. Salvador, Brazil, pp. 24-29

Priest DT, Knuffel WE, Malan FS (1982) End-splitting in Eucalyptus grandis sawlogs and sawn timber. Special report-National Timber Research Institute, Pretoria-South Africa, pp. iii +20 pp

Severo ET, Calonego FW, de Matos CA (2010) Lumber quality of Eucalyptus grandis as a function of diametrical position and $\log$ steaming. Bioresour Technol 101:2545-2548. doi:10.1016/j. biortech.2009.11.083

Shmulsky R (2002) Effect of log storage on structural veneer processing. For Prod J 52:82-84

Valencia J, Harwood C, Washusen R, Morrow A, Wood M, Volker P (2011) Longitudinal growth strain as a $\log$ and wood quality predictor for plantation-grown Eucalyptus nitens sawlogs. Wood Sci 45: 15-34. doi:10.1007/s00226-010-0302-1

Wolfinger R, Chang M (1995) Comparing the SAS GLM and MIXED procedures for repeated measures. SAS Institute Inc., Cary, NC, p 11

Yang JL (2005) The impact of log-end splits and spring on sawn recovery of 32-year-old plantation Eucalyptus globulus Labill. Holz Roh Werkst 63:442-448. doi:10.1007/s00107-005-0035-2

Yang JL, Bailleres H, Okuyama T, Muneri A, Downes G (2005) Measurement methods for longitudinal surface strain in trees: a review. Aust For 68:34-43 